DOI: 10.15593/RZhBiomeh/2016.2.02

УДК 531/534:[57+61]

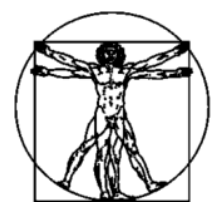

Росеийекий Журнал

\title{
МЕХАНИЧЕСКИЕ СВОЙСТВА БИОИНЖЕНЕРНОГО ПРОТЕЗА ТРАХЕИ НА ОСНОВЕ СИНТЕТИЧЕСКОГО УЛЬТРАВОЛОКНИСТОГО МАТРИКСА
}

\author{
М.В. Киселевский ${ }^{1}$, Н.Ю. Анисимова ${ }^{1}$, А.Д. Шепелев ${ }^{2}$, Т.Х. Тенчурин ${ }^{2}$, \\ В.Г. Мамагулашвили ${ }^{2}$, С.В. Крашенинников ${ }^{2}$, Т.Е. Григорьев ${ }^{2}$, \\ О.В. Лебединская ${ }^{3}$, С.Н. Чвалун ${ }^{2}$, М.И. Давыдов ${ }^{1}$ \\ ${ }^{1}$ Российский онкологический научный центр имени Н.Н. Блохина, Россия, 115478, Москва, Каширское ш., \\ 24, e-mail: kisele@,inbox.ru \\ ${ }^{2}$ Национальный исследовательский центр «Курчатовский институт», Россия, 123098, Москва, \\ пл. Академика Курчатова, 1, e-mail: shepelev_alexey@mail.ru \\ ${ }^{3}$ Пермский государственный медицинский университет им. академика Е.А. Вагнера, Россия, 614000, \\ Пермь, ул. Петропавловская, 26, e-mail: lebedinska@mail.ru
}

\begin{abstract}
Аннотация. Создание биосовместимых протезов трахеи для замещения дефектов данного органа, возникающих при злокачественных новообразованиях и травмах, является актуальной и нерешенной задачей медицины. Перспективным направлением служит создание тканеинженерных конструкций биопротезов трахеи на основе синтетических материалов. Как было показано ранее, матрикс трахеи, сконструированный с использованием метода 3D-прототипирования на основе ультраволокнистного полимерного нетканого материала, армированного полиуретановыми полукольцами, обладал механическими свойствами, приближающимися к нативной трахее. Цель настоящего исследования сравнительная характеристика механических свойств синтетического матрикса трахеи и полученной на его основе биоинженерной конструкции (биоимплантата) после заселения мезенхимальными мультипотентными (стволовыми) клетками (МСК) собак-реципиентов. Синтетические матриксы трахеи перед имплантацией экспериментальным собакам породы бигль заселяли МСК, полученными из костного мозга собак-реципиентов, которым в последующем имплантировали биоимплантаты в межмышечное пространство. Через один месяц биоимплантаты извлекали и оценивали их прочностные характеристики и показатели упругости с использованием универсальной испытательной машины «Инстрон 5965» с компьютерной системой анализа данных. Показано, что тканеинженерная конструкция на основе синтетического матрикса через один месяц после имплантации экспериментальным животным по своим механическим свойствам достоверно не отличалась от исходного синтетического матрикса трахеи на основе ультраволокнистого полимерного материала. Полученные результаты позволяют заключить, что процесс заселения синтетического матрикса трахеи клетками реципиента в условиях in vitro и при воздействии внутренней среды организма при
\end{abstract}

\footnotetext{
(c) Киселевский М.В., Анисимова Н.Ю., Шепелев А.Д., Тенчурин Т.Х., Мамагулашвили В.Г., Крашенинников С.В., Григорьев Т.Е., Лебединская О.В., Чвалун С.Н., Давыдов М.И., 2016 Киселевский Михаил Валентинович, д.м.н., профессор, заведующий лабораторией клеточного иммунитета, Москва

Анисимова Наталья Юрьевна, д.б.н., ведущий научный сотрудник лаборатории клеточного иммунитета, Москва

Шепелев Алексей Дмитриевич, к.Х.н., ведущий научный сотрудник, Москва

Тенчурин Тимур Хасянович, к.х.н., научный сотрудник, Москва

Мамагулашвили Виссарион Георгиевич, к.т.н., Москва

Крашенинников Сергей Всеволодович, к.т.н., старший научный сотрудник, Москва

Григорьев Тимофей Евгеньевич, к.ф.-м.н., заместитель начальника отдела, Москва

Лебединская Ольга Витальевна, д.м.н., профессор кафедры гистологии, эмбриологии и цитологии, Пермь

Чвалун Сергей Николаевич, д.х.н., Москва

Давыдов Михаил Иванович, д.м.н., профессор, академик Российской академии наук, Москва
} 
имплантации собакам существенно не изменяет механических свойств биоимплантата, что свидетельствует о целесообразности проведения дальнейших доклинических исследований с целью оценки перспективности использования биопротеза для замещения дефектов трахеи у онкологических больных и пациентов с травмами трахеи.

Ключевые слова: механические свойства, биоинженерная конструкция, трахея, ультраволокнистый матрикс, мезенхимальные стволовые клетки.

\section{ВВЕДЕНИЕ}

Замещение значительных дефектов трахеи, необходимое при различных патологических состояниях (опухоли трахеи и соседних органов, травмы, аномалии развития), требует создания биосовместимых протезов трахеи, обладающих механическими характеристиками, сходными с нативным органом [2, 3, 7, 9-11]. В настоящее время отсутствуют рекомендованные для клинической практики протезы трахеи. Одним из перспективных направлений в данной области является создание биоинженерных конструкций, для которых используют деиммунизированную (десселлюляризированную) донорскую трахею или синтетические скаффолды, заселяемые клетками потенциального реципиента $[7,16]$. Процесс децеллюляризации (удаление клеток трахеи) осуществляется посредством химической (биохимической) обработки или воздействия физических факторов, что может приводить к изменению механических свойств трахеи. В частности, было показано, что длительная биохимическая обработка нативной трахеи приводит к снижению ее прочности и каркасности за счет воздействия на структурные элементы хрящевого матрикса (глюкозаминогликаны) $[12,14,16,17,21]$.

Современные полимерные материалы, уже зарекомендовавшие себя в клинической практике в качестве протезов сосудов и тканей, могут явиться альтернативой донорской трахее [3, 4, 15]. Недавние исследования показали, что пористые матриксы на основе производных полиуретана, созданные методом $3 D$-прототипирования, могут быть использованы для получения биоинженерных протезов трахеи, которые по своим механическим свойствам приближаются к нативному органу $[4,13,15,21]$. Благодаря своей биосовместимости они хорошо колонизируются клетками как в условиях in vitro, так и при имплантации в целостный организм. Подобные биоинженерные протезы трахеи на основе синтетических матриксов, заселенных мезенхимальными мультипотентными (стволовыми) клетками (МСК) костного мозга реципиентов, были трансплантированы нескольким пациентам для замещения значительных циркулярных дефектов трахеи [6]. Авторами была разработана оригинальная конструкция матрикса трахеи на основе ультраволокнистого фторопласта, армированная полиуретановыми полукольцами. Ранее было показано, что ультраволокнистый матрикс по своим механическим свойствам приближается к нативной трахее [4].

Целью настоящего исследования является сравнение механических характеристик синтетического матрикса и биоинженерной конструкции, полученной на его основе, после имплантации экспериментальным животным.

\section{УСЛОВИЯ ПРОВЕДЕНИЯ ЭКСПЕРИМЕНТА}

Синтетические матриксы трахеи для исследований на собаках были изготовлены из нетканого материала на основе фторопласта методом электроспиннинга на опытной однокапиллярной установке для электроспиннинга. 
Полукольца, армирующие нетканый полимерный материал, получали методом термопрессования, в качестве исходного материала использовали полиуретан.

Исследования проведены на шести собаках породы бигль, содержащихся в условиях вивария и отделения экспериментальной терапии Российского онкологического научного центра им. Н.Н. Блохина. Все манипуляции с лабораторными животными выполнены в соответствии с международными рекомендациями по проведению медико-биологических исследований с использованием животных, изложенными в «Европейской конвенции по защите позвоночных животных, используемых для экспериментальных и других научных целей» (ЕЭС, Страсбург, 1985, 1986), требованиями Хельсинкской декларации и Всемирной медицинской ассоциации (2000).

Матриксы трахеи заселяли мезенхимальными мультипотентными клетками, выделенными из костного мозга собак. Полученные биоинженерные конструкции имплантировали в межмышечное пространство паховой области животных. Через один месяц биоимпланты извлекали для исследования механических свойств в сравнении с синтетическими матриксами трахеи (без заселения МСК).

Оценку механических свойств образцов синтетических матриксов трахеи и биоимплантатов, извлеченных через один месяц после имплантации собакам, проводили по описанной ранее методике [4]. Для этих целей от каждого образца
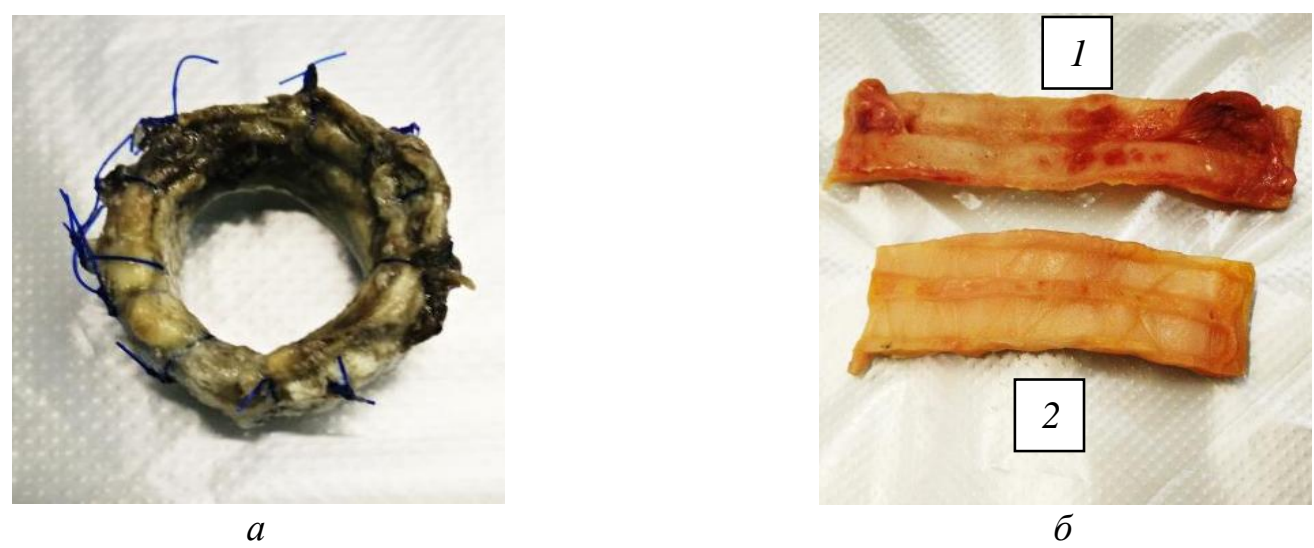

Рис. 1. Фрагменты биоимплантата трахеи перед испытаниями: $a$ - участок с полиуретановыми кольцами; $\sigma$ - внешний (1) и внутренний (2) слои нетканого материала
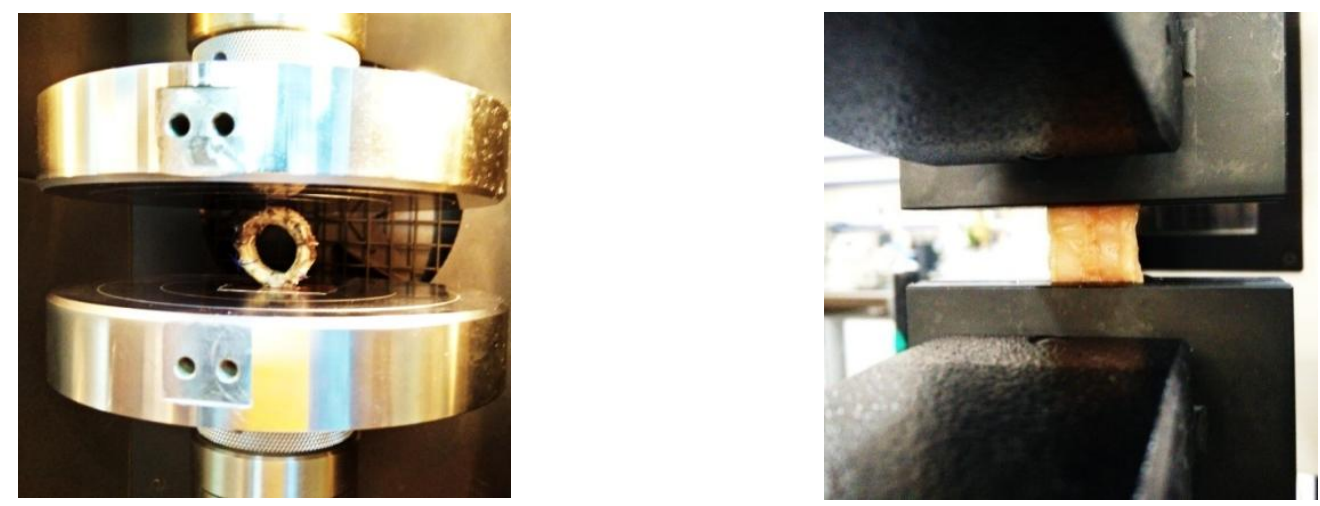

Рис. 2. Оценка механических свойств образцов с помощью универсальной испытательной машины «Инстрон 5965» с компьютерной системой анализа данных в рабочем режиме 
синтетического матрикса и биоимплантата отбирали фрагменты для испытаний участок, включающий полиуретановые полукольца шириной $10,0 \pm 0,1$ мм (рис. $1, a$ ) и фрагменты нетканого слоя длиной $50,0 \pm 0,1$ мм и шириной $15,00 \pm 0,05$ мм (рис. 1, б).

Расчет прочности $P$ проводили по формуле, определяя условное сечение образцов через их массу и плотность соответствующего полимера [1]:

$$
P=\frac{F_{\mathrm{p}}}{C_{\text {усл }}}=\frac{1 \cdot \rho \cdot F_{\mathrm{p}}}{m},
$$

где $F_{\mathrm{p}}$ - разрывная нагрузка, $\mathrm{H}$; $\mathrm{C}_{\text {усл }}$ - длина рабочей части образца, м; $\rho-$ плотность полимера, кг $/ \mathrm{M}^{3} ; m$ - масса рабочей части образца, кг. Модуль Юнга рассчитывали по стандартным методикам [5]. Результаты исследования прочностных свойств материалов приведены с указанием стандартной ошибки.

Участок биоимплантата или матрикса, включающий полукольца, исследовали на однократное сжатие с определением показателя кольцевой жесткости при вертикальном изменении внутреннего диаметра на $20 \%$, рассчитанного по ASTMD 2412-02, и на многократное сжатие: падение развиваемой нагрузки после 1000 циклов сжатия на $20 \%$ внутреннего диаметра в сравнении с первым циклом. Испытания проводили в среде фосфатного буфера при температуре $23 \pm 1{ }^{\circ} \mathrm{C}$.

Исследование механических свойств образцов осуществляли с использованием универсальной испытательной машины «Инстрон 5965» с набором зажимов и платформ для испытаний на растяжение и на сжатие (рис. 2). Измерение параметров проводили через 3-5 ч после извлечения образцов. До этого образцы находились в стерильном $0,9 \%$-ном растворе хлорида натрия при $-4{ }^{\circ} \mathrm{C}$.

\section{РЕЗУЛЬТАТЫ ЭКСПЕРИМЕНТОВ}

Для оценки изменений механических свойств имплантированного биоинженерного протеза и матрикса изучали прочностные характеристики фрагментов нетканой части матрикса, которая конструкционно является аналогом мягкотканой части нативной трахеи, а также упругость целостного фрагмента матрикса. С этой целью измеряли условную прочность слоев матрикса при разрыве, а также определяли показатель кольцевой жесткости при однократном сжатии и относительный показатель падения развиваемой нагрузки. Результаты приведены в табл. 1 и 2.

Таблица 1

\section{Прочностные характеристики мягкотканого матрикса трахеи}

\begin{tabular}{|c|c|c|c|c|}
\hline \multirow{2}{*}{$\begin{array}{c}\text { Критерий } \\
\text { статистического } \\
\text { анализа }\end{array}$} & \multicolumn{2}{|c|}{$\begin{array}{c}\text { Условная прочность } \\
\text { при разрыве, МПа }\end{array}$} & \multicolumn{2}{c|}{ Условный модуль Юнга, МПа } \\
\cline { 2 - 5 } & матрикс & биоимплантат & матрикс & биоимплантат \\
\hline Среднее значение & 13,5 & 15,7 & 29,5 & 32,1 \\
\hline Медиана & 13,5 & 15,7 & 29,5 & 32,1 \\
\hline SDсале 1-90 & 0,91 & 0,88 & 5,84 & 5,22 \\
\hline Минимум & 12,2 & 14,0 & 23,0 & 29,9 \\
\hline Максимум & 14,6 & 16,7 & 38,8 & 41,1 \\
\hline $25 \%$-ный квартиль & 12,7 & 14,5 & 22,0 & 31,3 \\
\hline
\end{tabular}


М.В. Киселевский, Н.Ю. Анисимова, А.Д. Шепелев, Т.Х. Тенчурин, В.Г. Мамагулашвили, С.В. Крашенинников, Т.Е. Григорьев, О.В. Лебединская, С.Н. Чвалун, М.И. Давыдов

Таблийа 2

Упругость фрагмента матрикса, армированного полукольцами на основе полиуретана

\begin{tabular}{|c|c|c|c|c|}
\hline \multirow{2}{*}{$\begin{array}{c}\text { Критерий } \\
\text { статистического } \\
\text { анализа }\end{array}$} & \multicolumn{2}{|c|}{$\begin{array}{c}\text { Многократное сжатие - } \\
\text { показатель падения развиваемой } \\
\text { нагрузки, }\end{array}$} & \multicolumn{2}{|c|}{$\begin{array}{c}\text { Однократное сжатие - } \\
\text { показатель кольцевой } \\
\text { жесткости, КПа }\end{array}$} \\
\cline { 2 - 5 } & матрикс & биоимплантат & матрикс & биоимплантат \\
\hline Среднее значение & 8,2 & 7,6 & 42,6 & 38,3 \\
\hline Медиана & 8,2 & 7,6 & 43,4 & 38,2 \\
\hline SDсаse 1-90 & 0,41 & 0,06 & 3,33 & 0,12 \\
\hline Минимум & 7,6 & 7,6 & 38,2 & 38,2 \\
\hline Максимум & 8,6 & 7,7 & 47,2 & 38,4 \\
\hline 25 \%-ный квартиль & 7,8 & 7,6 & 39,2 & 38,2 \\
\hline $75 \%$-ный квартиль & 8,6 & 7,7 & 44,0 & 38,4 \\
\hline
\end{tabular}

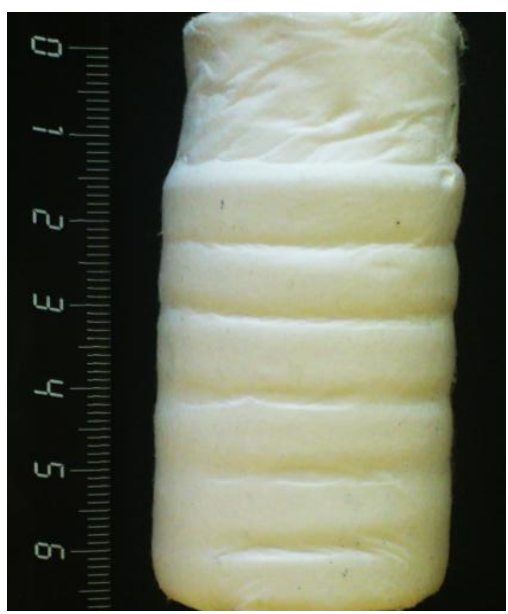

$a$

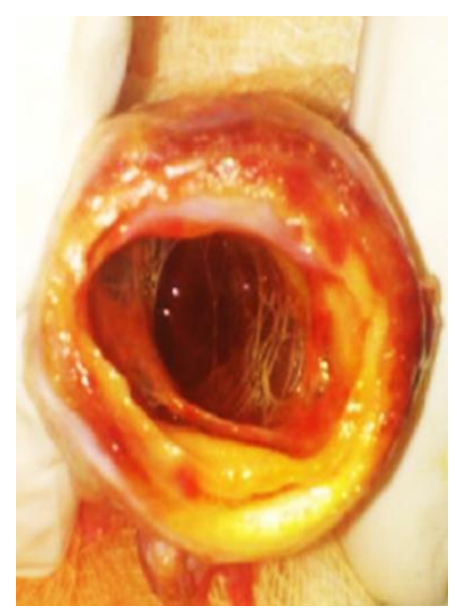

$\sigma$

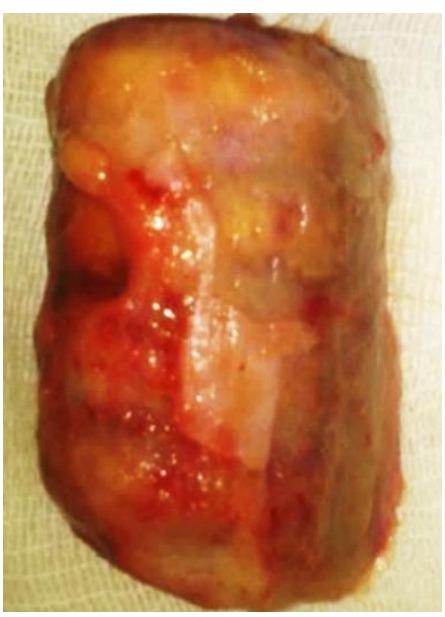

B

Рис. 3. Синтетический матрикс (a), биоимплантат трахеи (б) и биоимплантат трахеи (вид сбоку) (в)

Как следует из представленных фотографий (рис. 3), после одного месяца имплантации биоинженерная конструкция не теряет своих конфигуративных свойств и каркасности и сохраняет просвет. По своим механическим свойствам биоимплантаты достоверно не отличались от исходного синтетического матрикса трахеи. Однако прочностные характеристики биоинженерного протеза, включая условную прочность при разрыве и условный модуль Юнга, имели тенденцию к увеличению по сравнению с аналогичными показателями для синтетического матрикса трахеи. При анализе показателей упругости биоимплантата, напротив, отмечалась тенденция к их снижению по сравнению с исходным синтетическим матриксом трахеи.

\section{Выводы}

Таким образом, через один месяц после имплантации экспериментальным животным тканеинженерная конструкция на основе синтетического матрикса по своим механическим свойствам достоверно не отличалась от исходного синтетического матрикса трахеи на основе ультраволокнистого полимерного материала. Полученные результаты позволяют заключить, что заселение синтетического матрикса трахеи мезенхимальными стволовыми клетками реципиента в условиях in vitro и in vivo (воздействие внутренней среды организма) при имплантации собакам существенно 
не изменяет механических свойств биоимплантата. Этот факт свидетельствует о целесообразности проведения дальнейших доклинических исследований с целью оценки перспективности использования биоинженерного протеза для замещения дефектов трахеи у онкологических больных и пациентов с травмами органа.

\section{СПИСОК ЛИТЕРАТУРЫ}

1. Кембровский Г.С. Приближенные вычисления и методы обработки результатов измерений в физике. Минск: Университетское, 1990. - 188 с.

2. Киселевский М.В., Анисимова Н.Ю., Лебединская О.В., Полоцкий Б.Е., Давыдов М.И. Гетеротопная трансплантация неиммуногенной трахеи, заселенной костномозговыми стромальными стволовыми клетками реципиента // Морфология. - 2012. - № 1. - С. 66-70.

3. Киселевский М.В., Ситдикова С.М., Анисимова Н.Ю., Полоцкий Б.Е., Давыдов М.И. Перспективные синтетические матриксы для реконструкции дефектов трахеи у онкологических больных // Вопросы онкологии. - 2015. - Т. 61 (3). - С. 323-328.

4. Киселевский М.В., Анисимова Н.Ю., Шепелев А.Д., Тенчурин Т.Х., Мамагулашвили В.Г., Крашенинников С.В., Григорьев Т.Е., Чвалун С.Н., Давыдов М.И. Механические свойства синтетических матриксов трахеи на основе полимерного ультраволокнистого материала // Вестник Пермского университета. Математика. Механика. Информатика. - 2015. - № 3. - С. 8-12.

5. Малкин А.Я., Аскадский А.А., Коврига В.В. Методы измерения механических свойств полимеров. М.: Химия, 1978. - $336 \mathrm{c.}$

6. Ajalloueian F., Lim M.L., Lemon G., Haag J.C., Gustafsson Y., Sjöqvist S., Beltrán-Rodríguez A., Del Gaudio C., BaigueraS., Bianco A., Jungebluth P., Macchiarini P. Biomechanical and biocompatibility characteristics of electrospun polymeric tracheal scaffolds // Biomaterials. - 2014. - Vol. 35. P. 5307-5315.

7. Crowley C., Birchall M., Seifalian A.M. Trachea transplantation: from laboratory to patient // J. Tissue Eng. Regen. Med. - 2015. - Vol. 9 (4). - P. 357-367.

8. Del Gaudio C., Baiguera S., Ajalloueian F., Bianco A., Macchiarini P. Are synthetic scaffolds suitable for the development of clinical tissue-engineered tubular organs? // J. Biomed. Mater. Res. - 2014. - Vol. 102. P. 2427-2447.

9. Haag J., Baiguera S., Jungebluth P., Barale D., Del Gaudio C., Castiglione F., Bianco A., Comin C.E., Ribatti D., Macchiarini P. Biomechanical and angiogenic properties of tissue-engineered rat trachea using genipin cross-linked decellularized tissue // Biomaterials. - 2012. - Vol. 33 (3). - P. 780-789.

10. Jones M.C., Rueggeberg F.A., Cunningham A.J., Faircloth H.A., Jana T., Mettenburg D., Waller J.L., Postma G.N., Weinberger P.M. Biomechanical changes from long-term freezer storage and cellular reduction of tracheal scaffoldings // Laryngoscope. - 2015. - Vol. 125 (1). - P. 16-22.

11. Jones M.C., Rueggeberg F.A., Faircloth H.A., Cunningham A.J., Bush C.M., Prosser J.D., Waller J.L., Postma G.N.,Weinberger P.M. Defining the biomechanical properties of the rabbit trachea // Laryngoscope. - 2014. - Vol. 124 (10). - P. 2352-2358.

12. Kojima K., Charles A. Tissue engineering in the trachea // Vacant the Anatomical Record. - 2014. Vol. 297. - P. 44-50.

13. Komura M., Komura H., Kanamori Y., Tanaka Y., Ohatani Y., Ishimaru T., Sugiyama M., Hoshi K., Iwanaka T. Study of mechanical properties of engineered cartilage in an in vivo culture for design of a biodegradable scaffold // Int. J. Artif. Organs. - 2010. - Vol. 33 (1). - P. 775-781.

14. Lange P., Greco K., Partington L., Carvalho C., Oliani S., Birchall M.A., Sibbons P.D., Lowdell M.W. Ansari pilot study of a novel vacuum-assisted method for decellularization of tracheae for clinical tissue engineering applications // J. Tissue Eng. Regen. Med. - 2015 (published online). DOI: $10.1002 /$ term.1979

15. Li G., Zhang J., Cui X., Zhao Y., Cao P., Lu L., Li X. Morphology and pathological changes of polytetrafluoroethylene artificial tracheal transplantation // ZhongguoXiu Fu Chong JianWaiKeZaZhi. 2014. - Vol. 28 (7). - P. 879-884.

16. Macchiarini P., Jungebluth P., Go T., Asnaghi M.A., Rees L.E., Cogan T.A., Dodson A., Martorell J., Bellini S., Parnigotto P.P., Dickinson S.C., Hollander A.P., Mantero S., Conconi M.T., Birchall M.A. Clinical transplantation of a tissue engineered airway // Lancet. - 2008. - Vol. 372. - P. 2023-2030.

17. Mettenburg D., Jones C.M., Rueggeberg F.A., Cunningham A.J., Faircloth H.A., Jana T., Waller J.L., Postma G.N., Weinberger P.M. Biomechanical changes from long-term freezer storage and cellular reduction of tracheal scaffoldings // Laryngoscope. - 2015. - Vol. 125. - P. 16-22.

18. Omori K., Tada Y., Suzuki T., Nomoto Y. Clinical application of in situ tissue engineering using a scaffolding technique for reconstruction of the larynx and trachea // Ann. Otol. Rhinol. Laryngol. 2008. - Vol. 117. - P. 673-678. 
19. Partington L., Mordan N.J., Mason C., Knowles J.C., Kim W., Lowdell M.W., Birchall M.A., Wall I.B. Biochemical changes caused by decellularization may compromise mechanical integrity of tracheal scaffolds // Acta Biomater. - 2013. - Vol. 9 (2). - P. 5251-5261.

20. da Silva T.H.G., Pazetti R., Aoki F.G., Guerreiro P.F., Valenga M.H., Deffune E., Evaristo T., Pêgo-Fernandes P.M., Moriya H.T. Assessment of the mechanics of a tissue-engineered rat trachea in an image-processing environment // Clinics. - 2014. - Vol. 69. - P. 500-503.

21. Sun F., Pan S., Shi H.C., Zhang F.B., Zhang W.D., Ye G., Liu X.C., Zhang S.Q., Zhong C.H., Yuan X.L. Structural integrity, immunogenicity and biomechanical evaluation of rabbit decelluarized tracheal matrix // J. Biomed. Mater. Res. A. - 2015. - Vol. 103 (4). - P. 1509-1519.

22. Walenga R.L., Longest P.W., Sundaresan G. Creation of an in vitro biomechanical model of the trachea using rapid prototyping // J. Biomech. - 2014. - Vol. 47 (8). - P. 1861-1868.

23. Wang W., Shi H., Lu D., Li H., Chen L., Lu Y., Zeng Y. Cellular biocompatibility and biomechanical properties of $\mathrm{N}$-carboxyethylchitosan/nanohydroxyapatite composites for tissue-engineered trachea // Artif. Cells Blood Substit. Immobil. Biotechnol. - 2012. - Vol. 40 (1-2). - P. 120-124.

24. Teng Z., Trabelsi O., Ochoa I., He J., Gillard J.H., Doblare M. Anisotropic material behaviours of soft tissues in human trachea: an experimental study // J. Biomechanics. - 2012. - Vol. 45. - P. 1717-1723.

\title{
MECHANICAL PROPERTIES OF BIOENGINEERED TRACHEAL PROSTHESIS BASED ON A SYNTHETIC ULTRAFIBROUS MATRIX
}

\author{
M.V. Kiselevskii, N.Yu. Anisimova, A.D. Shepelev, T.Kh. Tenchurin, \\ V.G. Mamagulashvili, S.V. Krasheninnikov, T.E. Grigoriev (Moscow, Russia), \\ O.V. Lebedinskaya (Perm, Russia), S.N. Chvalun, M.I. Davydov (Moscow, Russia)
}

Creating biocompatible prostheses for the replacement of tracheal defects of the body resulting in malignant neoplasms and injuries is relevant and unsolved problem of medicine. A promising direction is to create tissue-engineered constructions of trachea bioprosthesis from synthetic materials. The tracheal matrix constructed using the 3D prototyping method using ultrafibrous nonwoven polymeric material with reinforced polyurethane semicircles, as shown previously, has mechanical properties approaching native trachea. The purpose of this study was the comparison of mechanical properties of the synthetic matrix of the trachea obtained on the basis of its bioengineered design (bioimplant) after settling multipotent mesenchymal (stem) cells (MSCs) of dog recipients. Synthetic matrices of trachea before implantation of experimental beagle dogs were populated by MSCs derived from bone marrow of the recipient dogs, which were subsequently implanted to intermuscular space. After one month, bioimplantats were removed and their strength characteristics and elasticity parameters using a universal testing machine Instron 5965 with a computer system of data analysis were evaluated. It has been shown that such design based on a synthetic matrix in one month after implantation to the experimental animals in their mechanical properties were not significantly different from the original synthetic trachea matrix based on ultrafibrous polymeric material. The results allow us to conclude that the process of settlement of the synthetic matrix trachea by recipient cells at in vitro conditions and the impact of the internal environment of the body of dogs do not significantly alter the mechanical properties of bioimplant that demonstrated the feasibility of further preclinical studies to assess the perspectives of the bioprosthesis to replace defects of the trachea at cancer patients and patients with injuries of the trachea.

Key words: mechanical properties, bioengineered construction, trachea, ultrafibrous matrix, mesenchymal stem cells. 